\title{
Closed-Loop Supply Chain: A bibliometric and visualization analysis
}

\author{
Liudmyla Saher ${ }^{1 *}$, Liubov Syhyda ${ }^{1}$, Olena Korobets $^{1}$, and Tamara Berezianko ${ }^{2}$ \\ ${ }^{1}$ Sumy State University, Department of Marketing, Sumy, Ukraine \\ ${ }^{2}$ National University of Food Technologies, Labor Economics and Management Department, Kyiv, Ukraine
}

\begin{abstract}
Nowadays, enterprises have to be good for society, to take care of the environment, and to achieve profit at the same time. And the closed-loop supply chain helps them being so. However, there is a lack of bibliometric and visualization research in the area of "Closed-Loop Supply Chain". Thus, this research aims to present a bibliometric overview to define the current state of scientific production regarding "Closed-Loop Supply Chain". The review of 807 publications from the Scopus database (1995-2020) was conducted. Two combinations of words with the logical operator ("supply chain" AND "reverse logistics") were used. The "title, abstract, keywords" field of search in the Scopus database was done. The visualization of the results was made using VOSviewer program to graphically map the material. The study used the co-occurrence of keywords and co-authorship (country) analyses. As a result, the most productive authors and journals were defined. The most cited studies were determined. Country clusters and keywords (co-occurrence) clusters were represented. The obtained results of the analysis and graphical presentations are relevant, and they form the basis for a better understanding of the concept of Closed-Loop Supply Chain.
\end{abstract}

\section{Introduction}

In recent years, it becomes clear that the only way for human beings to continue living in conditions of transformation economy [1-4] is to start taking care of the Earth, to become more wasteful than before, to step on the path of sustainable development. Today companies willing not only to be competitive and minimize risks in the long term [5-18] but also willing to be socially responsible connect their systems with the sustainable processes.

The global concern about environmental issues keeps growing in recent years. Thus, the problems of sustainable development, sustainability, and waste management in different spheres are discussed in the following studies [19-28]. The importance of environmental investments and green bonds is shown by scientists in papers [29-38]. Also, the scientists in the papers [39-40] proved that sustainable development and sustainability make a huge impact on brand formation.

Arising importance of social responsibility in terms of environmental and sustainable development is discussed in the following studies [41-43]. So, the increasing interest in sustainable development over the years also made a huge impact on the fields connected with supply chain and logistics. New concepts have appeared. One of these concepts is the closed-loop supply chain [44-46].

The supply chain management concept is well-known and wide-used. It is about coordination, integration, efficiency, and value creation. Supply chain management is aimed at product development and distribution process optimization. It is about to produce and to sell better than others. But in modern conditions that's not enough. It is important to think globally.

If the company wants to be efficient and successful, it is time to look at the situation from the different points of view. And the closed-loop supply chain is about to help in it. The function of the closed-loop supply chain is to be social- and environment-oriented. When producers add a reverse chain to their classical supply chain, they make the first step to being better and taking care of the planet.

The importance of reverse supply chain implementation can be confirmed by following factors: first, the level of product consumption arises every year, at the same time products' life-cycles are getting shorter and shorter; secondly, no stability in consumers' tastes; thirdly, the necessity for the organization to warranty returns and product recalls. While using a reverse chain, enterprise benefits in different ways. Some enterprises use a reverse chain to show their sustainable position, to underline social responsibility and environmental care. For others, it is a great way to enhance sales performance, maximize profit, and reduce costs.

So, closed-loop supply chains involve not only forward supply chains to bring products and services to the end consumers [47-54], but also reverse supply chains [55-57].

Thus, a closed-loop supply chain aims to recover products' added value by taking them back from customers for reusing or remanufacturing them.

\section{Method}

To develop the problem of closed-loop supply chains more deeply we used a bibliometric analysis. The main reason

Corresponding author: lyudmila.sager@gmail.com 
for conducting a bibliometric analysis is to examine bibliographical material, define the main scientific directions in the sphere and interlinks between them, and understand the pros and cons of the studies. In addition, bibliometric analysis is a good tool to define the gaps in existing scientific researches and to define directions for further researches.

The bibliometric analysis in current research has a similar structure to many other bibliometric studies, for example, [58-64]. The bibliometric study in this paper involved seven steps and was aimed to collect data in the area of "Closed-Loop Supply Chain" (see Figure 1).

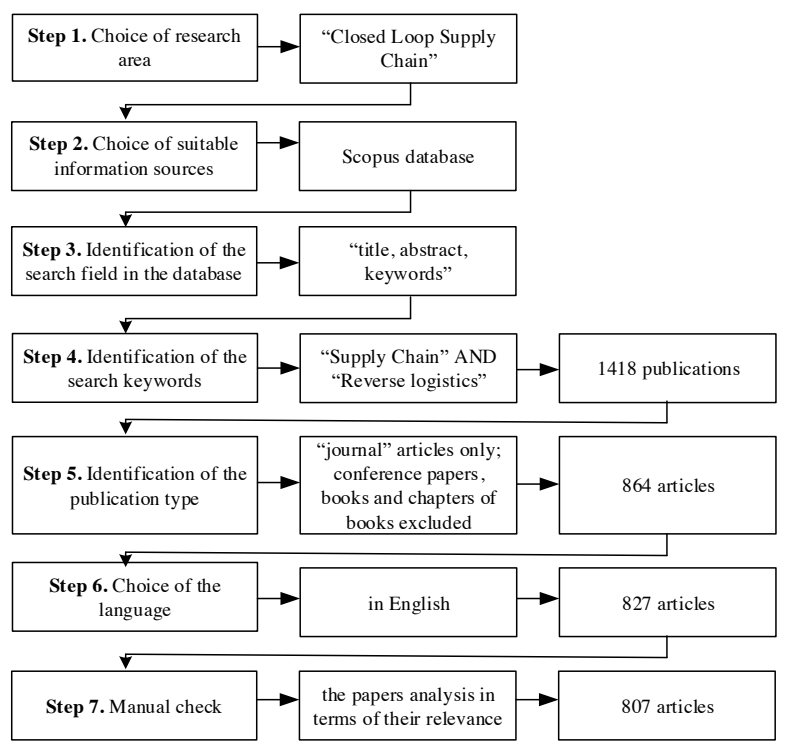

Fig. 1. Process of bibliometric analysis

The keywords used for data collection included "Supply Chain" and "Reverse Logistics". These two keywords were defined after the literature review of "Closed-Loop Supply Chain": most scientists agree that the closed-loop supply chain is a combination of these two keywords.

Thus, for further research 807 articles were chosen.

\section{Results and Discussion}

The distribution of scientific papers over the years is illustrated in Figure 2. According to the Figure, the first publications are dated 90-ties, but the main rapid growth started after 2005. We can highlight three stages in the publication trend. The first stage was between 1995-2004, the volume of studies was less than 10 studies per year. The second stage was between 2005-2012 when the volume of studies started growing moderately but was still less than 50 studies per year. Finally, during the third stage, from 2013 to 2019, the number of publications has increased from 62 to 101 . So, we can see the trend: the number of publications was increasing every year with the highest peak in 2019.

Also, this Figure shows us that more than $95 \%$ of studies were published within the last 15 years.

Analyzing the citation rate over the years we see that the highest rate of citations was in 2009 (3374 in total): two of three the most cited articles were published that year - Facility location and supply chain management - A review (Melo M.T., Nickel S., Saldanha-da-Gama F.) with total citation 1073 and The evolution of closed-loop supply chain research (Guide Jr. V.D.R., Van Wassenhove, L.N.) with total citation 724 (see Table 1).

The 10 Most Cited Publications found in Scopus in the area of "Closed-Loop Supply Chain" are in Table 1.

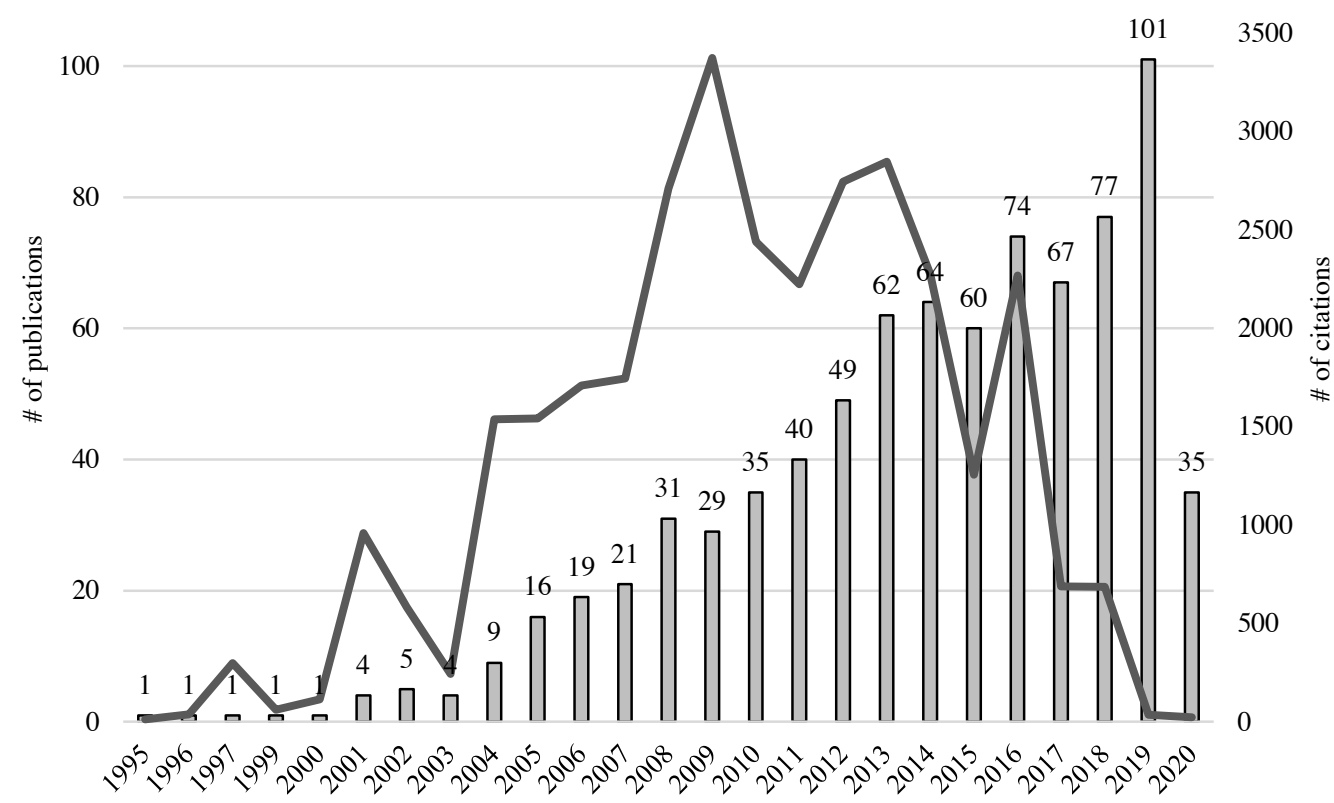

Fig. 2. Total number of publications and total number of citations in the area of "Closed-Loop Supply Chain" between 1995 and 2020 (based on Scopus Database) 
Table 1. The 10 most cited studies in the area of "Closed-Loop Supply Chain" between 1995 and 2020 (based on Scopus Database)

\begin{tabular}{|c|c|c|c|}
\hline $\begin{array}{c}\text { Total } \\
\text { citations }\end{array}$ & Author & Article title & Journal/Year of publication \\
\hline 1198 & $\begin{array}{c}\text { Savaskan R.C., } \\
\text { Bhattacharya S., } \\
\text { Van Wassenhove L.N. }\end{array}$ & $\begin{array}{l}\text { Closed-Loop Supply Chain Models with } \\
\text { Product Remanufacturing }\end{array}$ & Management Science,_2004 \\
\hline 1073 & $\begin{array}{l}\text { Melo M.T., Nickel S., } \\
\text { Saldanha-da-Gama F. }\end{array}$ & $\begin{array}{c}\text { Facility location and supply chain } \\
\text { management }- \text { A review }\end{array}$ & $\begin{array}{c}\text { European Journal of } \\
\text { Operational Research, } 2009 \\
\end{array}$ \\
\hline 724 & $\begin{array}{c}\text { Guide Jr. V.D.R., } \\
\text { Van Wassenhove, L.N. }\end{array}$ & $\begin{array}{c}\text { The evolution of closed-loop supply chain } \\
\text { research }\end{array}$ & Operations Research, 2009 \\
\hline 554 & $\begin{array}{l}\text { Brandenburg M., } \\
\text { Govindan K., } \\
\text { Sarkis J., Seuring S. } \\
\end{array}$ & $\begin{array}{l}\text { Quantitative models for sustainable supply } \\
\text { chain management: developments and } \\
\text { directions }\end{array}$ & $\begin{array}{c}\text { European Journal of } \\
\text { Operational Research, } 2014\end{array}$ \\
\hline 547 & $\begin{array}{l}\text { Fleischmann M., Beullens P., } \\
\text { Bloemhof-Ruwaard J.M., } \\
\text { Van Wassenhove L.N. }\end{array}$ & $\begin{array}{c}\text { The impact of product recovery on logistics } \\
\text { network design }\end{array}$ & $\begin{array}{l}\text { Production and Operations } \\
\text { Management, } 2001\end{array}$ \\
\hline 501 & $\begin{array}{c}\text { Savaskan R.C., } \\
\text { Van Wassenhove L.N. }\end{array}$ & $\begin{array}{c}\text { Reverse channel design: The case of competing } \\
\text { retailers }\end{array}$ & Management Science, 2006 \\
\hline 471 & $\begin{array}{l}\text { Chaabane A., Ramudhin A., } \\
\text { Paquet M. }\end{array}$ & $\begin{array}{l}\text { Design of sustainable supply chains under the } \\
\text { emission trading scheme }\end{array}$ & $\begin{array}{c}\text { International Journal of } \\
\text { Production Economics, } 2012\end{array}$ \\
\hline 413 & $\begin{array}{l}\text { Lin C., Choy K.L., } \\
\text { Ho G.T.S., Chung S.H., } \\
\text { Lam H.Y. } \\
\end{array}$ & $\begin{array}{c}\text { Survey of Green Vehicle Routing Problem: } \\
\text { Past and future trends }\end{array}$ & $\begin{array}{l}\text { Expert Systems with } \\
\text { Applications, } 2014\end{array}$ \\
\hline 413 & $\begin{array}{c}\text { Rogers D.S., } \\
\text { Tibben-Lembke R. }\end{array}$ & An examination of reverse logistics practices & $\begin{array}{c}\text { Journal of Business Logistics, } \\
2001 \\
\end{array}$ \\
\hline 364 & $\begin{array}{c}\text { Pishvaee M.S., } \\
\text { Rabbani M., Torabi S.A. }\end{array}$ & $\begin{array}{l}\text { A robust optimization approach to closed-loop } \\
\text { supply chain network design under uncertainty }\end{array}$ & $\begin{array}{l}\text { Applied Mathematical } \\
\text { Modelling, } 2011\end{array}$ \\
\hline
\end{tabular}

The most cited article, with 1198 citations, is ClosedLoop Supply Chain Models with Product Remanufacturing, written by Savaskan R.C., Bhattacharya S., Van Wassenhove L.N. [65]. In this study, the authors highlighted the importance of designing effective remanufacturing systems for companies to increase their profit and used-product return rate. For this purpose, they proposed to choose one of three possible supply chain models with remanufacturing.

The second place takes the article by Melo M.T., Nickel S., Saldanha-da-Gama F. Facility location and supply chain management - A review [66]. It has been cited 1073 times. In this paper, the authors have made a deep literature review of the facility location models in the context of supply chain management. Also, the structure of the supply chain network, including reverse logistics, supply chain performance measures, and optimization techniques were additionally reviewed by them. The obtained results revealed the growing trend in supply chain planning - the integration of strategic and tactical/operational decisions.

And in the third place is a study by Guide Jr., V.D.R., Van Wassenhove, L.N. [67] The evolution of closed-loop supply chain research, with 724 citations. In this study, the authors within five phases have described the evolution in the field of closed-loop supply chains.

It should be mentioned that Van Wassenhove L.N. (coauthor of the 1st and 3rd articles) is in the top 10 contributing authors (see Table 2). Also, many studies on the list were published in the early 2000th.

The frequency of the author's name appearance based on the data from Scopus is in Table 2.

As the Table reveals, the top three contributors to the research area are the following scientist K. Govindan, Diabat A., and Amin S.H. Additionally, it was found that almost $33 \%$ of all articles were published in top 10 journals.

Table 2. The number of published articles by top 10 contributing authors and top 10 journals in the area of "Closed-Loop Supply Chain" between 1995 and 2020 (based on Scopus Database)

\begin{tabular}{|c|c|c|c|c|}
\hline Author & $\begin{array}{c}\text { Number of } \\
\text { published articles }\end{array}$ & Journal & SNIP & $\begin{array}{c}\text { Number of } \\
\text { published articles }\end{array}$ \\
\hline Godivan K. & 18 & Journal of Cleaner Production & 2.308 & 54 \\
\hline Diabat A. & 12 & International Journal of Production Economics & 2.486 & 45 \\
\hline Amin S.H. & 10 & International Journal of Production Research & 1.720 & 43 \\
\hline Zhang G. & 9 & Computers And Industrial Engineering & 1.755 & 19 \\
\hline Van Wassenhove L.N. & 8 & International Journal of Advanced Manufacturing Technology & 1.596 & 19 \\
\hline Hazen B.T. & 7 & International Journal of Logistics Systems And Management & 0.758 & 18 \\
\hline Jaber M.Y. & 7 & International Journal of Supply Chain Management & 0.599 & 18 \\
\hline Kannan G. & 7 & International Journal of Physical Distribution & 2.109 & 17 \\
\hline Kumar S. & 7 & And Logistics Management & 2.455 & 14 \\
\hline Richev R.G. & 7 & European Journal Of Operational Research & 2 & 1.134 \\
\hline
\end{tabular}




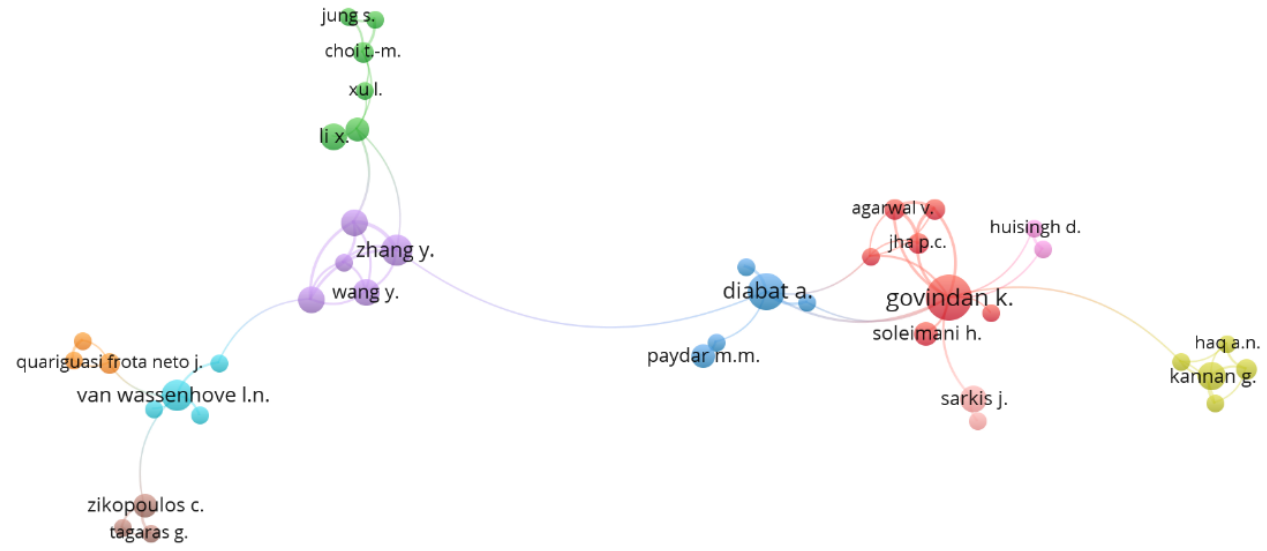

Fig. 3. Network of relationships between authors (minimum three documents in common) (based on Scopus Database), generated using VOSviewer

Moreover, as we can see from Figure 3, five the most contributing authors form five main scientific clusters Godivan K., Diabat A., Zhang G., Van Wassenhove L.N. and Kannan G. Also, Godivan K. works in an international group with Diabat A., and Diabat A. cooperates with Zhang G.

Figure 4 shows a network that illustrates the main publishing countries in the area of "closed-loop supply chain". As a result, eleven country clusters were formed. Four countries have leading positions in this research area. They are the USA (156 documents, 11843 citations), India (120 documents, 3305 citations), China (81 documents, 1788 citations), and the United Kingdom (65 documents, 1845 citations). These four countries form the main clusters, and they are followed by Iran (75 documents, 2651 citations) and Canada (46 documents, 2927 citations). Other clusters are smaller.

To identify the most frequent keywords relevant to the area, the network of relationships between keywords (co-occurrence) was formed (using VOSviewer).

Figure 5 illustrates the main keywords used and the size of the nodes. The program created thirteen clusters. They represent the 175 keywords with the most frequent co-occurrences. Different clusters are illustrated in different colors.

The same color of the nodes and keywords means that they belong to the same cluster. The most common keywords leading the main clusters are: "reverse logistics" - 536 occurrences (orange), "logistics" 294 occurrences (yellow), "supply chains" - 285 occurrences (light blue), "supply chain management" 246 occurrences (brown), "closed-loop supply chains" 137 occurrences (gold), "recycling" - 96 occurrences (blue), "sustainable development" -85 occurrences (red), "remanufacturing" - 73 occurrences (light green).

The integral result of the conducted analysis is the determination of the relationship between the main aspects of the research and the identification of the most problematic areas in the field of Closed-Loop Supply Chain. In the future, obtained results will allow us to focus on unexplored aspects of the scientific problem and increase its value.

\section{Conclusions}

The article analyzed and defined the concept of closedloop supply chain concentrating on the use of bibliometrics. A bibliometric analysis was carried out with a sample of 807 scientific papers in total and has shown that the rapid growth of the publications started after 2005. Regarding the countries, the greatest number of articles were published by the authors from the United States, the United Kingdom, China, and India.

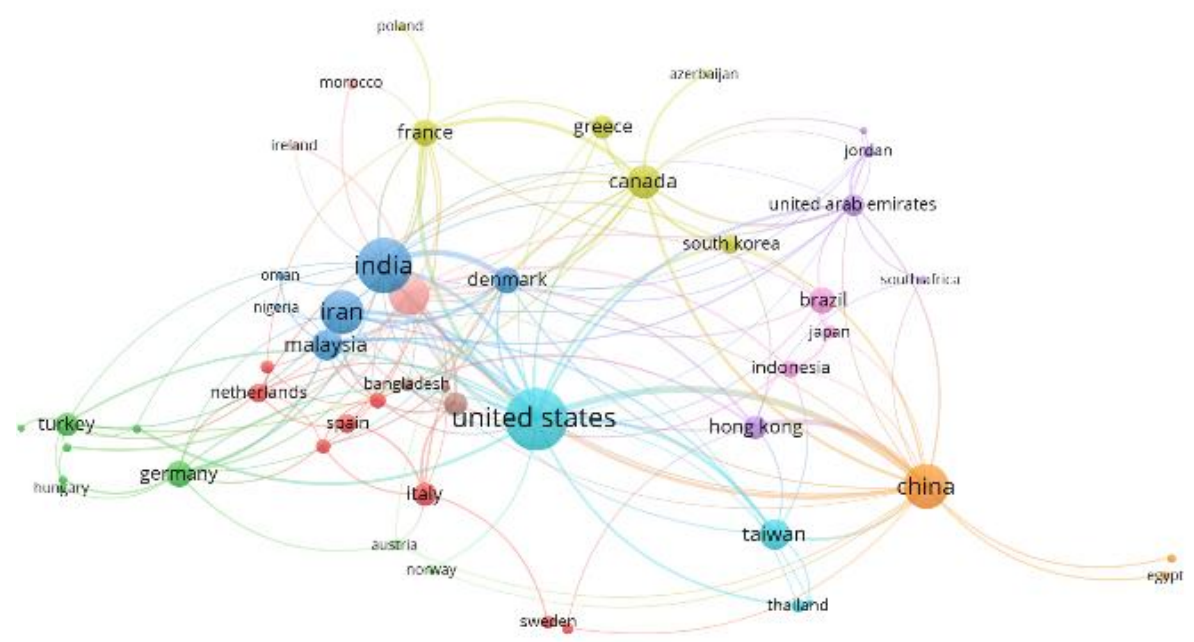

Fig. 4. The network of relationships between countries (based on Scopus Database), generated using VOSviewer 


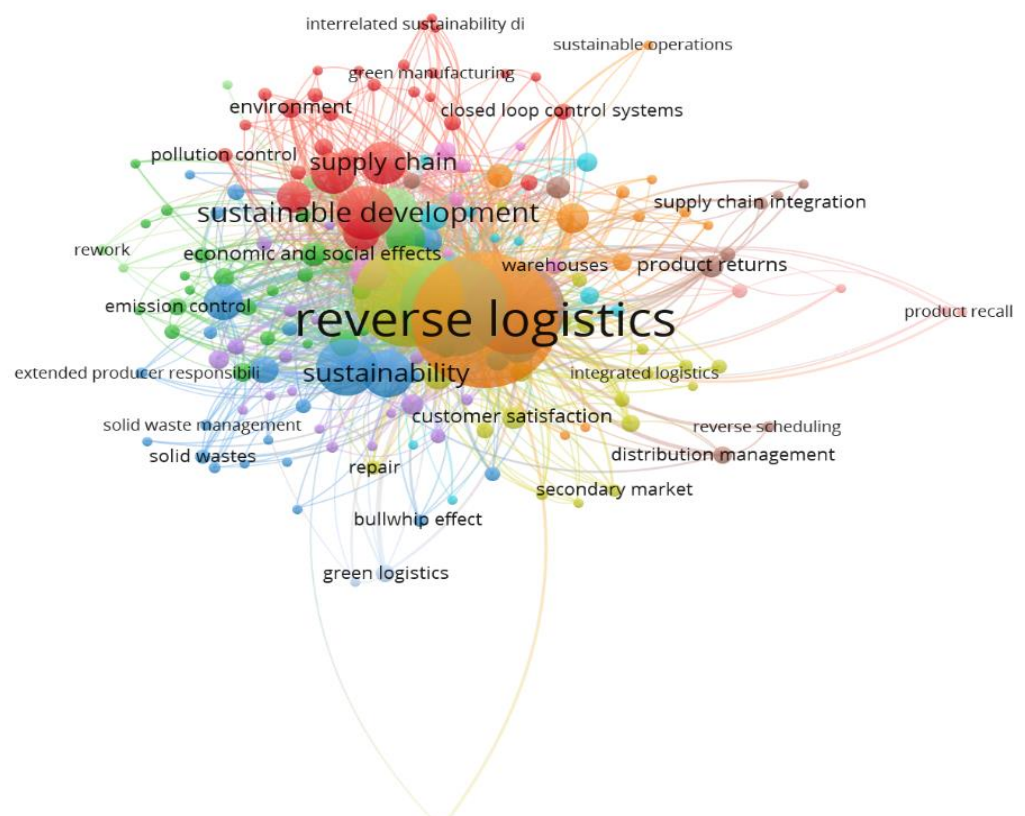

Fig. 5. Network of relationships between keywords (based on Scopus Database), generated using VOSviewer

The top journals in the area were Journal of Cleaner Production, International Journal of Production Economics, and International Journal of Production Research.

The three most cited articles are focused on the supply chain management and closed-loop supply chain and have total citation 2995.

Finally, this study improves our understanding of how the closed-loop supply chain concept has been developed, helps to define its main components, and highlights the further research trends.

We will focus our further researches on using other software and methodologies to extend bibliographic studies and reach more fruitful scientific results. Also, to deeper the obtained results, we will analyze some of the clusters and themes of this research in more detail to identify the gaps and ways of their overlapping.

\section{References}

1. T. Vasilyeva, O. Kuzmenko, V. BoHzhenko, O. Kaolotilina. Assessment6 of the dynamics of bifurcation transformations in the economy, in SHS Web of Conferences, EDP Sciences, 65, 134-146 (2019).

2. L. Rui, L. Sineviciene, L. Melnyk, O. Kubatko, O. Karintseva, O. Lyulyov. Economic and environmental convergence of transformation economy: The case of China, Problems and Perspectives in Management, 17(3), 233-241 (2019).

3. Y. Bilan, M. Brychko, A. Buriak, T. Vasilyeva. Financial, business and trust cycles: The issues of synchronization, Zbornik Radova Ekonomskog Fakultet au Rijeci, 37(1), 113-138 (2019).
4. A.(Abi) Moskovicz. Helping State Agent to understand the Private Sector, Financial Markets, Institutions and Risks, 2(1), 75-78 (2018).

5. Y. Khan. The Effectiveness of Entrepreneurial Activities for Economic Development: A Route to Innovation and Job Generation, SocioEconomic Challenges, 2(2), 34-40 (2018).

6. A. Kwilinski. Mechanism of modernization of industrial sphere of industrial enterprise in accordance with requirements of the information economy, Marketing and management of innovations, 4, 116-128 (2018).

7. M. Bublyk, V. Koval, O. Redkva. Analysis impact of the structural competition preconditions for ensuring economic security of the machine building complex, Marketing and management of innovations, 4, 229-240 (2017).

8. O. Ryabenkov, T. Vasyliyeva. Comprehensive approach to application of financial controlling methods in the context of efficient application of profitability potential, Actual Problems of Economics, 148(10), 160-165 (2013).

9. O. Olefirenko, Y Nagornyi, O Shevliuga. Methodical approach to estimation of industrial enterprises' technical and technological development level, Actual Problems of Economics, 158(8), 464-470 (2014).

10. L. Zakharkina. Balancing of innovative development of machine-building enterprises in strategic planning process, Actual Problems of Economics, 3, 88-95 (2009).

11. O. Karpishchenko, G. Peresadko, O. Olefirenko. Enterprise management systems: The case of "primary radiology group", Actual Problems of Economics, 154(4), 218-227 (2014).

12. A. Grenčíková, Y. Bilan, Y. Samusevych, A. Vysochyna. Drivers and inhibitors of entrepreneurship development in central and 
eastern European countries, in Proceedings of the 33rd International Business Information Management Association Conference, IBIMA, 2536-2547 (2019).

13. Y. Bilan, S. Lyeonov, T. Vasylieva, Y. Samusevych. Does tax competition for capital define entrepreneurship trends in Eastern Europe? Online Journal Modelling the New Europe, 27, 34-66 (2018).

14. L. Hrytsenko, T. Krasulya. Risk management at realization of infrastructure projects under publicprivate partnership, Actual Problems of Economics, 126(12), 85-90 (2011).

15. I. Skliar, A. Samoilikova. Risk evaluation at enterprise innovation and investment activity financing, Actual Problems of Economics, 161(11), 173-178 (2014).

16. A. Masharsky, G. Azarenkova, K. Oryekhova, $\mathrm{S}$. Yavorsky. Anti-crisis financial management on energy enterprises as a precondition of innovative conversion of the energy industry: case of Ukraine, Marketing and management of innovations, 3, 345354 (2018).

17. Md. Nur-Al-Ahad, N. Syeda, P. Vagavi. Nexus Between Corporate Governance and Firm Performance in Malaysia: Supervised Machine Learning Approach, Financial Markets, Institutions and Risks, 3(1), 115-130 (2019).

18. A. Karaoulanis. Strategic Transformation and Innovation towards Blue Ocean Creation in a Changing Corporate Reality, Business Ethics and Leadership, 2(2), 49-55 (2018).

19. N. Kostyuchenko, Y. Petrushenko, D. Smolennikov, Y. Danko. Community-based approach to local development as a basis for sustainable agriculture: Experience from Ukraine, International Journal of Agricultural Resources, Governance and Ecology, 11(2), 178-189 (2015).

20. O. Lyulyov, T. Pimonenko, N. Stoyanets, N. Letunovska. Sustainable development of agricultural sector: Democratic profile impact among developing countries, Research in World Economy, 10(4), 97-105 (2019).

21. I. Kendiukhov, M. Tvaronavičienè. Managing innovations in sustainable economic growth, Marketing and Management of Innovations, 3, 3342 (2017).

22. H. Dkhili. Environmental performance and institutions quality: evidence from developed and developing countries, Marketing and Management of Innovations, 3, 333-244 (2018).

23. Y. Bilan, S. Lyeonov, N. Stoyanets, A. Vysochyna. The impact of environmental determinants of sustainable agriculture on country food security, International Journal of Environmental Technology and Management, 21(5-6), 289-305 (2018).

24. T. Bondar, Y. Matvieieva, I. Myroshnychenko. Assessment of the social, ecologic and economic development of machine building enterprises, Economic Annals-XXI, 7-8(1), 40-44 (2015).

25. L. Hrytsenko, M. Petrushenko, K. Daher. The necessity of socio-ecological modification of two- tier economic model of secondary resources management in Ukraine, SocioEconomic Challenges, 1(1), 68-76 (2017).

26. S. He. The Impact of Trade on Environmental Quality: A Business Ethics Perspective and Evidence from China, Business Ethics and Leadership, 3(4), 43-48 (2019).

27. T. Shevchenko, I. Koblianska, L. Saher. Development of biodegradable municipal waste separate collection system in Ukraine to fulfill the requirements of the European union directives, Journal of Environmental Management and Tourism. 7(3), 361-369 (2016).

28. Y. Yevdokimov, O. Chygryn, T. Pimonenko, O. Lyulyov. Biogas as an alternative energy resource for Ukrainian companies: EU experience, Innovative Marketing, 14(2), 7-15 (2018).

29. O. Chygryn, V. Krasniak. Theoretical and applied aspects of the development of environmental investment in Ukraine, Marketing and management of innovations, 3, 226-234 (2015).

30. S. Lyeonov, T. Pimonenko, Y. Bilan, D. Streimikiene, G. Mentel. Assessment of green investments' impact on sustainable development: Linking gross domestic product per capita, greenhouse gas emissions and renewable energy, Energies, 12(20), 3891 (2019).

31. G. Peresadko, E. Kovalenko, L. Kulyk. Mechanisms of investing into innovative projects of enterprises, Actual Problems of Economics, 160(1), 184-187 (2014).

32. N. Kotenko, T. Illyashenko. Fiscal decentralization and the challenges of public ecological services deliveryo, Marketing and management of innovations, 2, 267-278 (2015).

33. O. Chygryn, T. Pimonenko, O. Luylyov, A. Goncharova. Green Bonds like the Incentive Instrument for Cleaner Production at the Government and Corporate Levels: Experience from EU to Ukraine, Journal of Environmental Management and Tourism, 9(7), 1443 (2019).

34. T. Pimonenko, Y. Myroshnychenko, O. Korobets, O. Lytvynenko. Ecological stock indexes: foreign experience and lessons for Ukraine, Bulletin of Sumy State University. Economy Ser, 4, 121-127 (2017).

35. L. Hrytsenko. Systematization of scientific approaches to public-private partnership in the field of investment, Actual Problems of Economics, 170(8), 8-15 (2015).

36. O. Chygryn, T. Pimonenko, O. Luylyov, A. Goncharova. Green bonds like the incentive instrument for cleaner production at the government and corporate levels: Experience from EU to Ukraine, Journal of Environmental Management and Tourism, 9(7), 1443-1456 (2018).

37. L. Sokolenko, I. Tiutiunyk, D. Leus. Ecological and economic security assessment in the system of regional environmental management: A case study of Ukraine, International Journal of Ecology and Development, 32(3), 27-35 (2017). 
38. Y. Chirichenko, N. Fisunenko. Methodical bases of the proposal evaluation of investment resources in the construction industry, Financial Markets, Institutions and Risks, 2(3), 76-86 (2018).

39. T. Pimonenko, Y. Bilan, J. Horák, L. Starchenko, W. Gajda. Green brand of companies and greenwashing under sustainable development goals, Sustainability (Switzerland), 12(4), 1679 (2020).

40. Y. Bilan, S. Lyeonov, O. Lyulyov, T. Pimonenko. Brand management and macroeconomic stability of the country, Polish Journal of Management Studies, 19(2), 61-74 (2019).

41. M.P.S.R. Mercado, J. Vargas-Hernández. Analysis of the Determinants of Social Capital in Organizations, Business Ethics and Leadership, 3(1), 124-133 (2019).

42. O. Tielietov, N. Letunovska. Organizational and economic mechanism of industrial enterprises social infrastructure management, Actual Problems of Economics, 160(1), 329-337 (2014).

43. I. Myroshnychenko, I. Makarenko, D. Smolennikov, A. Buriak. The approach to managing corporate social and environmental responsibility in manufacturing, TEM Journal, 8(3), 740-748 (2019).

44. V.D.R. Guide Jr., T. Harrison, L. Van Wassenhove. The Challenge of Closed-Loop Supply Chains, in Proceedings of LCE2006 - 13th CIRP International Conference on Life Cycle Engineering, 11-13 (2003).

45. N. Kumar, R. Kumar. Closed Loop Supply Chain Management and Reverse Logistics -A Literature Review. International Journal of Engineering Research and Technology, 6(4), 455-468 (2013).

46. I. Sahebia, B. Masoomib, S. Ghorbanic, T. Uslud. Scenario-based designing of closed-loop supply chain with uncertainty in returned products, Decision Science Letters, 8(4), 505-518 (2019).

47. O. Bilovodska, L. Syhyda, L. Saher. Supply chain management: world's companies experience, MIND Journal, 5, 1-17 (2018).

48. L. Taraniuk, J. Wang, H. Qiu, Y. Petrushenko, $\mathrm{K}$. Taraniuk. International aspects of assessing the logistic potential of the main countries of agricultural production, Problems and Perspectives in Management, 17(3), 31-44 (2019).

49. O. Bilovodska, N. Gaidabrus, L. Sager. Logistic service in innovative products distribution channels as a factor of optimal structure, Actual Problems of Economics, 161(11), 147-153 (2014).

50. L. Syhyda. Influence of enterprise's marketing environment on process of marketing distribution policy development, Economic Annals-XXI, 7-8(2), 28-32 (2013). L. Syhyda, N. Syhyda. Place and role of supply chains in the agricultural industry of Ukraine, Visnyk of Sumy State University, Economy Ser, 3, 74-82 (2019).

51. L. Syhyda, N. Syhyda. Supply chains efficiency evaluation: methodological aspect, Businessnavigator, 2(41), 63-69 (2017).

52. A. Balas, H. Kaya. The Global Economic Crisis And Retailers' Security Concerns: The Trends, SocioEconomic Challenges, 3(2), 5-14 (2019).
53. L. Mura, M. Marchevska, M. Dubravska. Slovak retail business across panel regression model, Marketing and Management of Innovations, 4, 203211 (2018).

54. O. Olefirenko. Theoretical and methodic grounds to identify potential sales markets of innovative production for Ukrainian machine building enterprises, Problems and Perspectives in Management, 13(4), 63-69 (2015).

55. S. Rubio, B. Jiménez-Parra. Reverse Logistics: Overview and Challenges for Supply Chain Management, International Journal of Engineering Business Management, 6(12), 1-7 (2014).

56. M. Fleischmann, J. Van Nunen, B. Gräve, R. Gapp. Reverse Logistics - Capturing Value in the Extended Supply Chain, in ERIM Report Series Research in Management, 167-186 (2004).

57. M. Kosacka-Olejnik, K. Werner-Lewandowska. Reverse logistics as a trend of XXI century - state of art, Management Systems in Production Engineering 2020, 28(1), 9-14 (2020).

58. G. Albort-Morant, J. Henseler, A. Leal-Millán, G. Cepeda-Carrión. Mapping the Field: A Bibliometric Analysis of Green Innovation, Sustainability, 9(6), 1011 (2017).

59. Y. Bilan, T. Pimonenko, L. Starchenko. Sustainable business models for innovation and success: Bibliometric analysis, in E3S Web of Conferences, 159, 04037 (2020).

60. N. Kazemi, N. Modak, K. Govindan. A review of reverse logistics and closed loop supply chain management studies published in IJPR: a bibliometric and content analysis, International Journal of Production Research, 57(15-16), 49374960 (2019).

61. B. Fahimnia, J. Sarkis, H. Davarzani. Green supply chain management: A review and bibliometric analysis, Int. J. Production Economics, 162, 101-114 (2015).

62. H. Shvindina. Coopetition as an Emerging Trend in Research: Perspectives for Safety \& Security, Safety 5(3) (2019).

63. M.D.L.M. Capobianco-Uriarte, M.D.P. CasadoBelmonte, G. Marín-Carrillo, E. Terán-Yépez. A Bibliometric Analysis of International Competitiveness (1983-2017), Sustainability, 11, 1877 (2019).

64. P. Hallinger, J. Kovačević. A Bibliometric Review of Research on Educational Administration: Science Mapping the Literature, 1960 to 2018, Review of Educational Research, 89(3), 335-369 (2019).

65. R. Savaskan, S. Bhattacharya, L. Van Wassenhove. Closed-Loop Supply Chain Models with Product Remanufacturing, Management Science, 50(2), 239252 (2004).

66. M. Melo, S. Nickel, F. Saldanha-da-Gama. Facility location and supply chain management - A review, European Journal of Operational Research, 196(2), 401-412 (2009).

67. V.D.R. Guide Jr., L. Van Wassenhove. The evolution of closed-loop supply chain research, Operations Research, 57(1), 10-18 (2009). 